\title{
Editorial - Coming of Age: Twenty-One Volumes of European Legal Studies
}

The publication of this volume of the Cambridge Yearbook of European Legal Studies marks a significant milestone in the history of the Yearbook. A project that began at the end of the last century has come of age in its twenty-first volume.

In their inaugural editorial, the founding editors of the Yearbook-Alan Dashwood and Angela Ward-described the focus of its contributions as being:

... on the Law of the European Union and of other European organisations, including the Council of Europe and its human rights jurisdiction; on the complex interactions between those supranational orders and the internal legal orders of European States; and on Comparative Law, as a source of inspiration for the solution of problems occurring at the European level.

Since then, the Yearbook has published in excess of 250 original research articles guided by the founding vision of an open and inclusive approach to European Legal Studies.

This year's volume reflects the maturing of a legal field that has expanded in substantive scope as well as deepened in intellectual depth. From social and environmental law to security and equality concerns conceptualised in constitutional terms, the articles presented in this volume showcase what is new and engaging about European Legal Studies. They also focus on topics beyond the Brexit crises, which has continued to play out on both sides of the English Channel and across the Irish Sea. Litigation before the Scottish, English, Northern Irish, and EU courts has also revealed the myriad ways in which domestic law and EU law interact within the field of European Legal Studies in addressing legal issues thrown up by the contested politics of Brexit.

This interaction between legal orders is something which the literature on 'constitutional pluralism' has sought to exploit and embrace. Yet its fundamental presuppositions as well its political implications have been challenged by various crisis in Europe. In this year's volume we welcome a new 'Symposium' feature to reflect on a topic that the editors consider deserves a sustained focus and the inaugural symposium analyses the state of play of this strand of literature. Cormac Mac Amhlaigh's contribution takes us back to Brexit via constitutional pluralism, finding that the interaction between EU and UK law post-membership may offer a surprising level of support to pluralist thinking. Wilkinson, however, sees the type of sovereignty claims inherent in Brexit and other EU crises as being in tension with the postsovereignty orientation of constitutional pluralism. The exploration of constitutional pluralism's presuppositions is also explored by Lawrence, who examines the limits of pluralism's 'tolerance' as a way of highlighting background assumptions 
necessary to prevent pluralism descending into conflict. Yet for Kelemen and Pech, it is the conflict that is readily apparent in the 'rule of law' crises facing the EU that highlights the risks of tolerance. Political forces are all too ready to weaponise ideas of respect for national constitutional identity towards illiberal ends, leading them to conclude that despite good intentions, advocates of constitutional pluralism may have to confront uncomfortable uses of its discourse and intellectual repertoire.

All of which illustrates that as we celebrate the twenty-first volume of the Yearbook, the editors are keen not just to hold true to the original vision of the founding editors but to continue to innovate and find new ways of advancing the contemporary mission of the Yearbook which is to:

... offer authors and readers a space for sustained reflection and conversation about the challenges facing Europe and the diverse legal contexts in which those challenges are addressed. It identifies European Legal Studies as a broad field of legal enquiry encompassing not only European Union law but also the law emanating from the Council of Europe; comparative European public and private law; and national law in its interaction with European legal sources

On behalf of the editors, we hope you will enjoy reading and re-reading these contributions from twenty-one years of European Legal Studies. The Yearbook is a publication of the Centre for European Legal Studies of the Faculty of Law, University of Cambridge. The editors are thankful for the support of the Centre and of its professional administrator Felicity Eves-Rey. They would also like to thank Rebecca O'Rourke and Jamie Davidson from Cambridge University Press for their continuing professionalism in publishing the Yearbook and especially Erin Lovall and Andrew Organ of the Press for ensuring the quality and timeliness of its production.

Cambridge

October 2019 